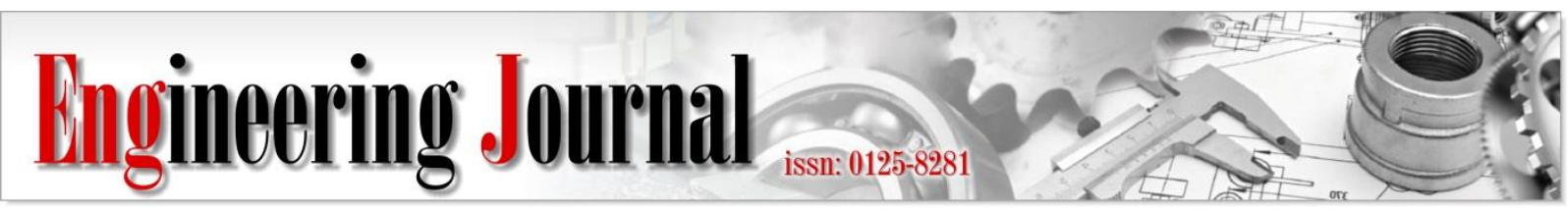

Article

\title{
Investigation on the Use Solar Thermoelectric Generator for Open Pond Cultivation with Heat Pipe Cooling
}

\author{
Imansyah Ibnu Hakim ${ }^{a,}$, Nandy Putra ${ }^{b}$, and Yovan Okta Ananda ${ }^{c}$ \\ Heat Transfer Laboratory, Department of Mechanical Engineering Universitas Indonesia, \\ Kampus UI, Depok 16424, Indonesia \\ E-mail: aimansyah@eng.ui.ac.id (Corresponding author), bnandyputra@eng.ui.ac.id,cyovan.okta@ui.ac.id
}

\begin{abstract}
At present, most aquaculture ponds get a supply of dissolved oxygen from pumps or aerators that use electricity. Whereas in some places, farmers still experience infrastructure problems such as roads, ports, and electricity. Generally, the cultivation pond water level is $0.3-0.5 \mathrm{ha}$, which can be rectangular or square. The large surface area of this pond has the potential to be utilized by its solar power. The thermoelectric module utilizes the Seebeck effect where if there is a heat difference between the two sides there will be an electric potential. The sun's heat can still be raised again by using a concentrator. Thermoelectric modules can produce electricity due to temperature differences on both sides. In aquaculture ponds, there is a lot of water that can be used to cool the thermoelectrics. One tool that can be used to deliver heat quickly is a heat pipe. Heat pipe is a passive device that has excellent heat transfer properties and high efficiency. In this research, heat pipes will be used as heat transfer media to cool the thermoelectric cold side. From the testing that has been done, the maximum voltage of the thermoelectric module is $3.77 \mathrm{~V}$ obtained from a temperature difference of $67.57^{\circ} \mathrm{C}$.
\end{abstract}

Keywords: Thermoelectric generator, heat pipe, cultivation pond, seebeck effect.

ENGINEERING JOURNAL Volume 24 Issue 4

Received 5 December 2019

Accepted 21 April 2020

Published 31 July 2020

Online at https://engj.org/

DOI:10.4186/ej.2020.24.4.295

This article is based on the presentation at The 4th International Tropical Renewable Energy Conference (i-TREC 2019) in Bali, Indonesia, 14 - 16 August 2019. 


\section{Introduction}

One sector that contributes to economic independence is the fisheries sector. Indonesia as one of the maritime countries has many potential fisheries. Data from the Ministry of Maritime Affairs and Fisheries shows a positive trend towards Indonesian fisheries exports. Exports of fishery products cannot be separated from the number of commodities produced. Contributors to the largest export value of fishery products are always dominated by shrimp. In 2017 the value of shrimp exports reached USD 1,700 [1].

The high shrimp export value is still not optimal because there are still many problems faced by shrimp farmers. Most shrimp are produced from freshwater pond culture which requires a supply of dissolved oxygen. At present, most aquaculture ponds get a supply of dissolved oxygen from pumps or aerators that use electricity [2]. Whereas in some places, farmers still experience infrastructure problems such as roads, traffic, and electricity [3]. In addition, $95 \%$ of 2.2 million Indonesians working in the fisheries sector are traditional workers who have limited knowledge and technology [4]. By increasing knowledge and technology farmers can increase fisheries production. Whereas an increase in fisheries production can increase the income of farmers and their communities [5].

Biologically, the supply of dissolved oxygen in aquaculture ponds is mostly from phytoplankton photosynthesis. More than $70 \%$ of the oxygen entering water comes from phytoplankton photosynthesis and more than $50 \%$ is consumed by phytoplankton as well [2] To do phytoplankton photosynthesis, it requires light with a range of 400-700 $\mathrm{nm}$ electromagnetic spectrum or also called Photosynthetically Active Radiation (PAR). The addition of light to the phytoplankton ecosystem can increase photosynthetic products so that cell metabolism increases. With increasing cell metabolism, the growth of phytoplankton will be faster [6]. At night light availability decreases, so the supply of dissolved oxygen is also getting smaller. The decrease in dissolved oxygen content takes place from the afternoon and continues to decrease at night [2]. In the study of dissolved oxygen, it was found that the use of LED on shrimp farms could increase the rate of dissolved oxygen [7].

The cultivation pond surface area is generally 0.3 0.5 ha, which can be rectangular or square in shape [8]. The large surface area of this pond has the potential to be utilized by harvesting its solar power. One of the most economical renewable energy devices that can convert solar heat into electricity is a thermoelectric module [9]. The thermoelectric module utilizes the Seebeck effect where if there is a heat difference between the two sides there will be an electric potential [10]. The sun's heat can still be raised again by using a concentrator. thermoelectric modules that use concentrators can increase temperatures up to ten times the ambient temperature [11].

Thermoelectric modules can produce electricity because of differences in temperature on both sides
[12],[13]. So that high solar heat is not only a major factor in generating electricity, the cold side also needs attention. The efficient way is to maintain heat transfer capacity is from the cold side [14]. Water is suitable to absorb heat on the cold side of the thermoelectric module [15]. In aquaculture ponds, there is a lot of water that can be used to cool thermoelectrics. The heat which is attached to the cold side can be easily be removed by cooling using water. However, the thermoelectric module that has an electrical system is not good if it is directly exposed to water. One tool that has high flux carrying capacity and effectivity is a heat pipe [16],[17]. Heat pipe is a passive device that has excellent heat transfer properties and high efficiency [18]. Heat pipes are widely used in the electronics industry, for example, batteries [19]. In this research, heat pipes will be used as heat transfer media to cool the thermoelectric cold side.

The purpose of this research was to determine the electrical energy produced by the thermoelectric module, the temperature that occurs in the heat pipe and the efficiency of the thermoelectric module.

\section{Methodology}

Testing is done using a laboratory-scale model. Instead of using heat from sunlight, a heater is used to provide heat to the heat side of the thermoelectric module [16]. The heater power source is obtained from the DC Power supply. The heat will flow due to the temperature difference on each side of the thermoelectric module and generate potential difference [20]. To obtain a temperature variation on the heat side of the thermoelectric module, a voltage variation from the DC power supply is used. Voltage variations on DC power supply are used $4 \mathrm{~V}, 8 \mathrm{~V}, 12 \mathrm{~V}, 16 \mathrm{~V}, 20 \mathrm{~V}$, and $24 \mathrm{~V}$. The thermoelectric module used is type SP1848-27145 SA with the Seebeck coefficient value of $0.09 \mathrm{~V} / \mathrm{K}$. Two thermoelectric modules are connected in series. Each thermoelectric module is connected with two heat pipes on the cold side. The test circuit was then isolated using polyurethane to reduce heat loss. The heat pipe used is an L-shape with dimensions of $15 \mathrm{~cm} \times 19 \mathrm{~cm}$ and a copper pipe diameter of $5 \mathrm{~mm}$. The heat pipe functions as a thermoelectric module heat exchanger. The part of the heat pipe attached to the cold side of the thermoelectric module functions as an evaporator. While the other end functions as a condenser. The condenser side of the heat pipe is dipped in the tub as a substitute for the open cultivation pond. The tub contains water circulating the Circulating Thermostatic Bath (CTB). The water temperature is made stable at $20^{\circ} \mathrm{C}$. The research body is made of Styrofoam to prevent heat from going out into the environment. The experimental setup can be seen in Fig. 1.

Data acquisition is done by using NI cDAQ-9174 data acquisition tool with additional module 9219 for voltage and current measurement, and module 9213 for temperature measurement. Sensor K-type thermocouples are used which are then positioned on several measurement points and can be seen in Fig. 2 and Fig. 3. 


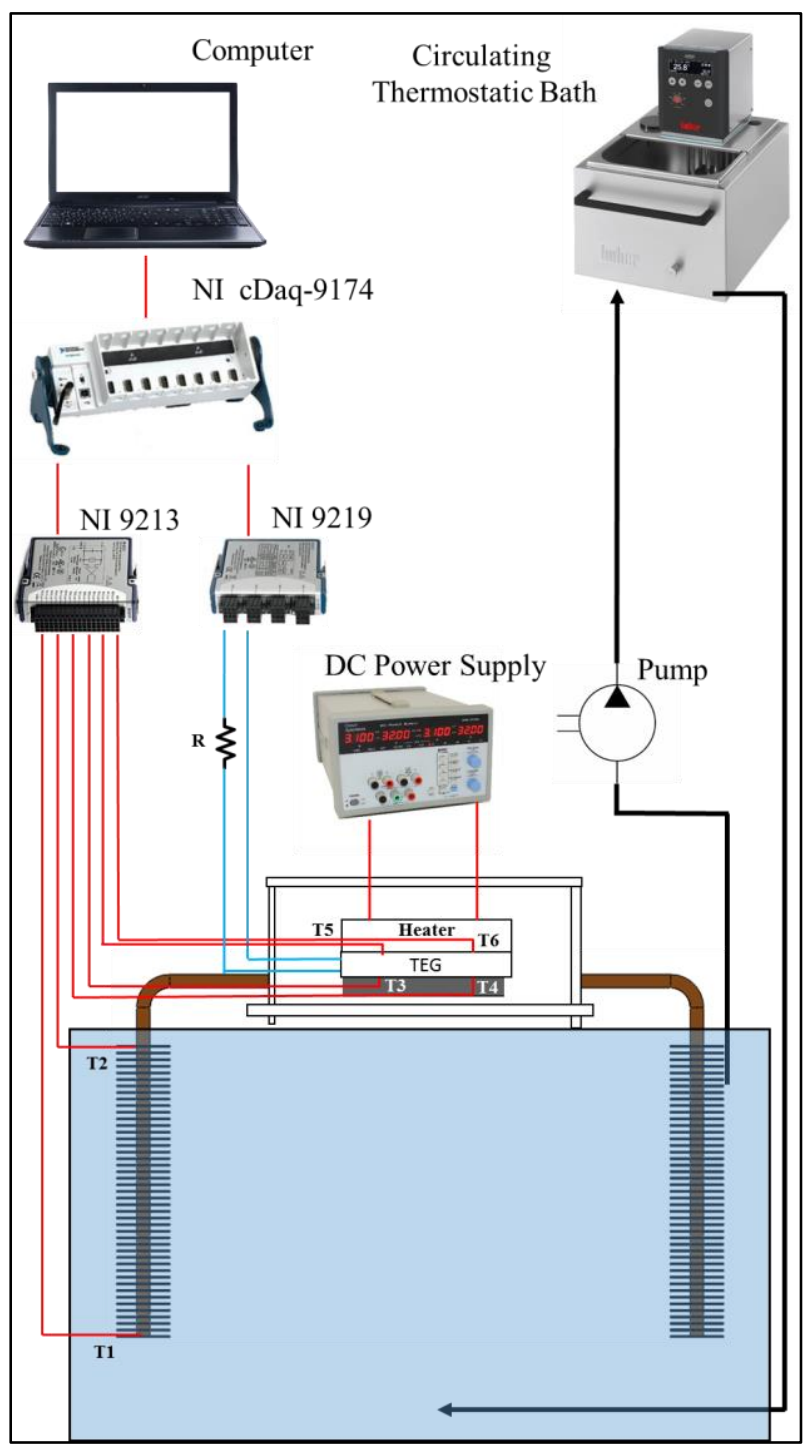

Fig. 1. Schematic of experimental setup of thermoelectric generator testing.

Some temperature measurement points are placed in the thermoelectric module on the hot side (T5 and T6), the cold side (T3 and T4) which is also the point of the evaporator of the heat pipe, and condenser point (T1 and T2). To get the power value generated by a thermocouple module an external load is required. A resistor of $210 \Omega$, $182 \Omega$, and $144 \Omega$ is arranged in series with the NI 9219 module as an external load.

To determine the voltage output [V] generated by the thermoelectric module, Eq. (1) is used. Where $\alpha$ is a Seebeck coefficient $\left[\mathrm{V} /{ }^{\circ} \mathrm{C}\right]$, Th and $\mathrm{Tc}$ are the temperature of the hot side and cold side thermoelectric module $\left[{ }^{\circ} \mathrm{C}\right]$. For electric current (I) is given by Eq. (2). Where $\mathrm{R}_{\mathrm{i}}$ and $\mathrm{R}_{\mathrm{L}}$ is internal resistant and external load in $\Omega$.

$$
\begin{gathered}
\alpha=\frac{\Delta V}{(T h-T c)} \\
I=\frac{\alpha(T h-T c)}{\left(R i+R_{L}\right)}
\end{gathered}
$$

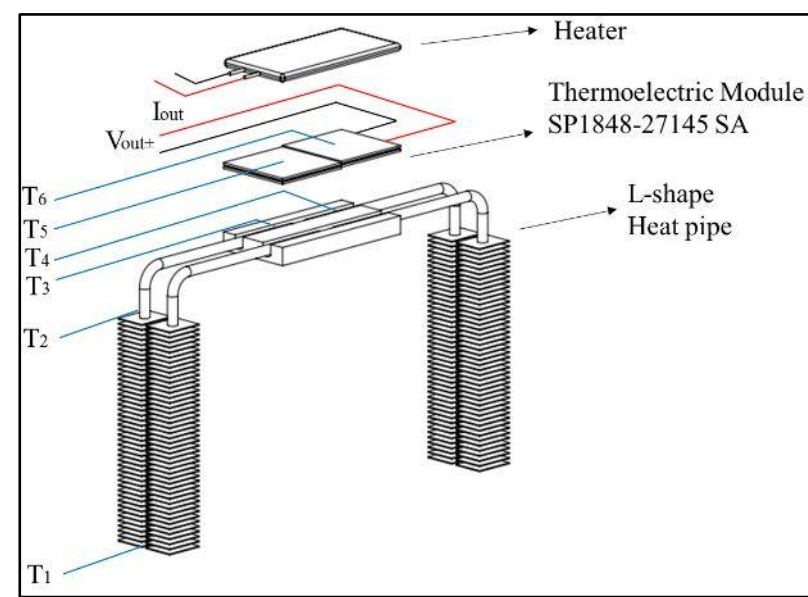

Fig. 2. Schematic of measurement point.

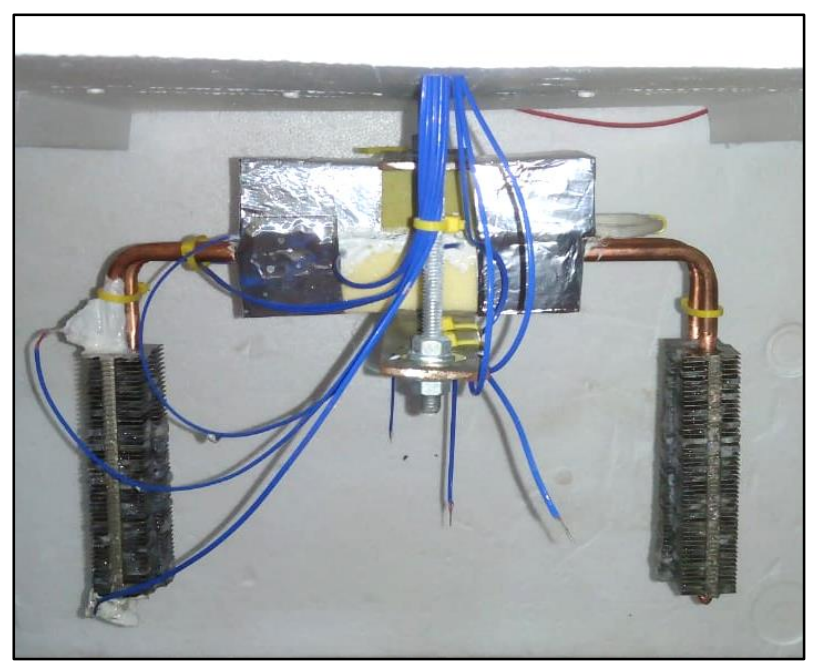

Fig. 3. Installation of measurement sensor.

Because of the temperature difference on both sides of the thermoelectric module, heat transfer occurs. Where the heat transfer rate is Qh [Watt], and $\mathrm{K}$ is the thermal conductivity of the thermoelectric module $\left[\mathrm{Watt} /{ }^{\circ} \mathrm{C}\right]$. The thermoelectric module heat transfer rate can be formulated as follows in Eq. (3) [12]. The amount of power $(\mathrm{P})$ generated in the thermoelectric module is formulated in Eq. (4). Whereas to know the efficiency $(\eta)$ of the thermoelectric module, Eq. (5) can be used [21].

$$
\begin{gathered}
Q_{h}=(\alpha \cdot I \cdot T h)+K(T h-T c) \\
P=I^{2} \cdot R_{L} \\
\eta=\frac{P}{Q_{h}}
\end{gathered}
$$

\section{Result and Discussion}

Tests are carried out using voltage variations on the heater using a DC power supply. Variations in the heater input voltage are $4 \mathrm{~V}, 8 \mathrm{~V}, 12 \mathrm{~V}, 16 \mathrm{~V}, 20 \mathrm{~V}$, and $24 \mathrm{~V}$. By measuring the electric current through the heater, the electric power used by the heater can be obtained. The amount of power in each variation can be seen in Table 1. 
Table 1. Experimental variation.

\begin{tabular}{ccc}
\hline $\begin{array}{c}\boldsymbol{V}_{\text {in }} \\
\text { (Volt) }\end{array}$ & $\begin{array}{c}\boldsymbol{I}_{\text {in }} \\
\text { (Ampere) }\end{array}$ & $\begin{array}{c}\boldsymbol{P}_{\text {in }} \\
\text { (Watt) }\end{array}$ \\
\hline 4 & 0.2 & 0.8 \\
8 & 0.5 & 4.0 \\
12 & 0.9 & 10.8 \\
16 & 1.2 & 19.2 \\
20 & 1.5 & 30.0 \\
24 & 1.8 & 43.2 \\
\hline
\end{tabular}

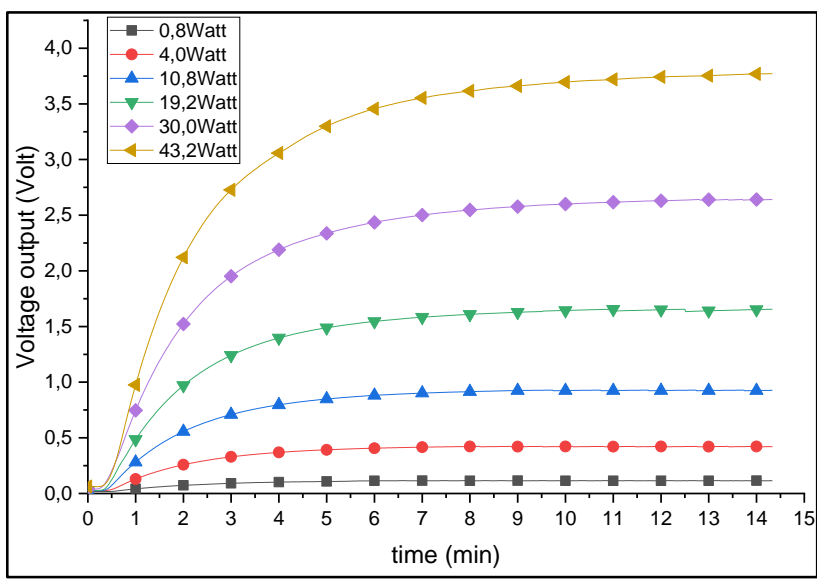

Fig. 4. Thermoelectric module voltage output at $210 \Omega$ load.

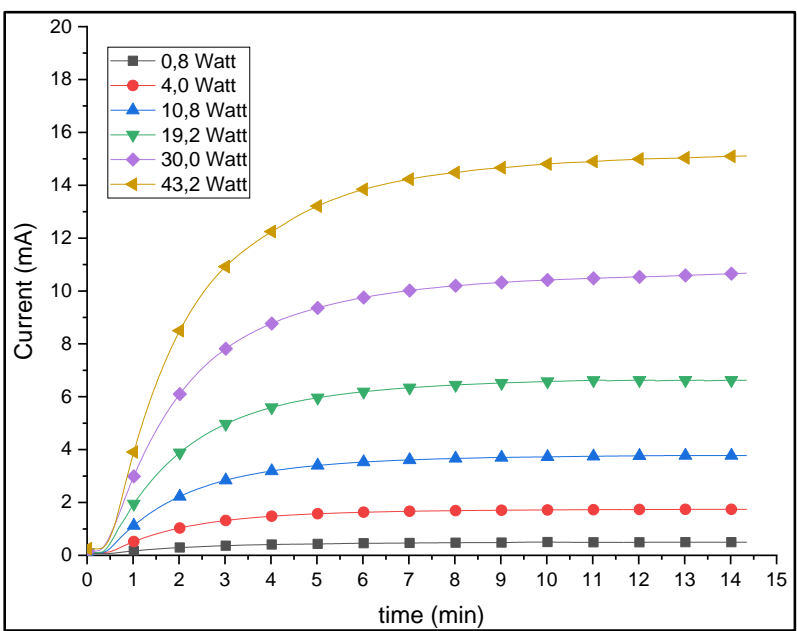

Fig. 5. Thermoelectric module current output at $210 \Omega$ load.

Table 1 can be seen as in variations in the input voltage used to produce different power. The variation is $0.8 \mathrm{~W}, 4.0 \mathrm{~W}, 10.8 \mathrm{~W}, 19.2 \mathrm{~W}, 30.0 \mathrm{~W}$, and $43.2 \mathrm{~W}$. This power difference is then used as an experimental variation on this paper

Acquisition data in each variation is carried out until the heater temperature reaches a stable value. Thus the value of the voltage measurement is stable for each variation. The results of voltage measurements at $210 \Omega$ loads on each variation can be seen in Fig. 4. The graph of Fig. 4 is the voltage output of the thermoelectric module compared to time.

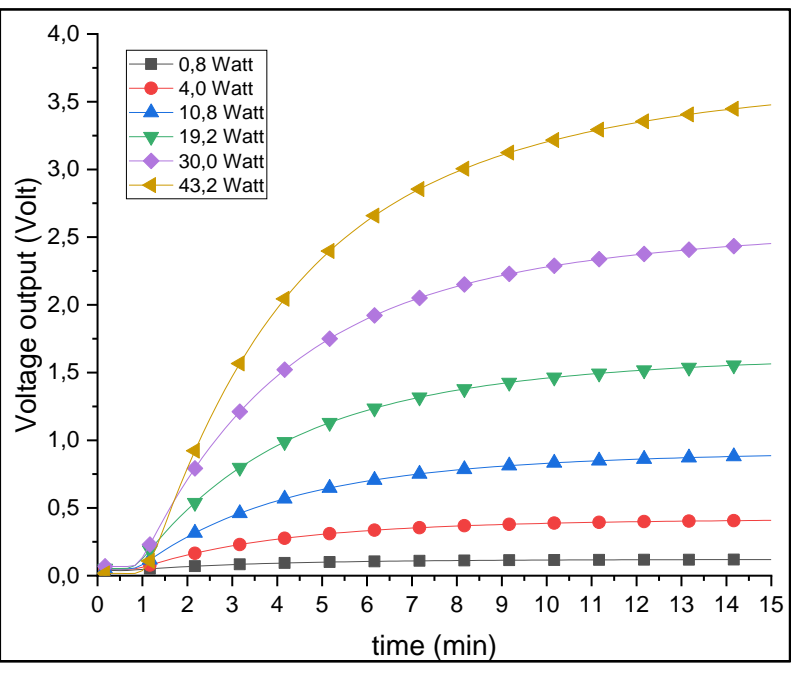

Fig. 6. Thermoelectric module voltage output at $182 \Omega$ load.

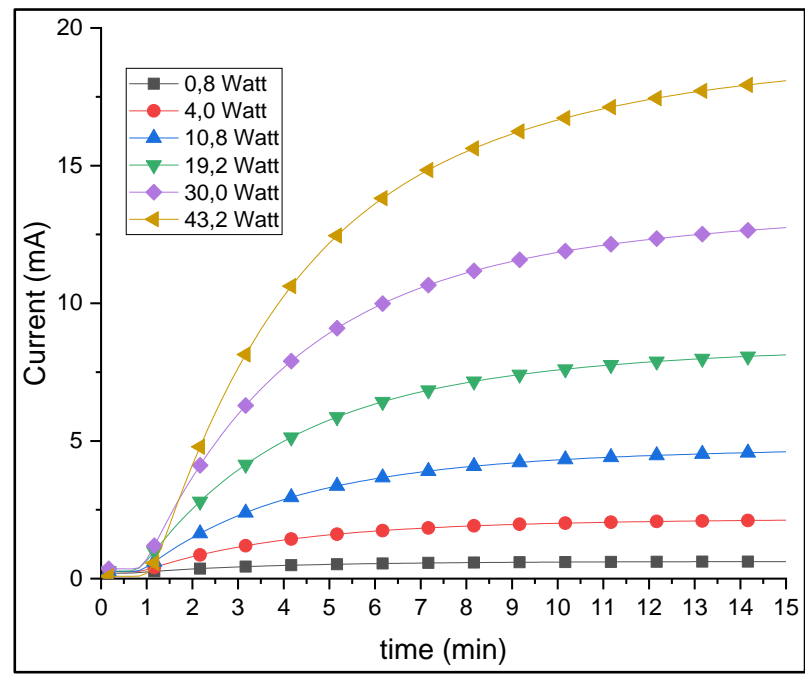

Fig. 7. Thermoelectric module current output at $182 \Omega$ load.

The thermoelectric module output voltage takes a certain amount of time to reach stability. The time is different in each voltage variation. The greater the voltage, the more time needed to achieve stability. Same as voltage output at the $210 \Omega$, the voltage output of 182 $\Omega$ and $144 \Omega$ also requires a certain amount of time to reach stability (Fig. 6 , and Fig. 8). The greater voltage generated the more time needed to reach stability. Fig. 5, Fig. 7, and Fig. 9 presented the current output of the thermoelectric module at each load of $210 \Omega, 182 \Omega$, and $144 \Omega$. Not much different from the output voltage, the current output also requires time to achieve stability. The higher the current produced, the longer the time to achieve stability.

Stability is needed in this experiment to maintain the consistency of the measurement so that no measurement error occurs. The average stability is achieved in the fifteen minutes so that the highest values of voltage and current for each variation on this paper are recorded at that time. 


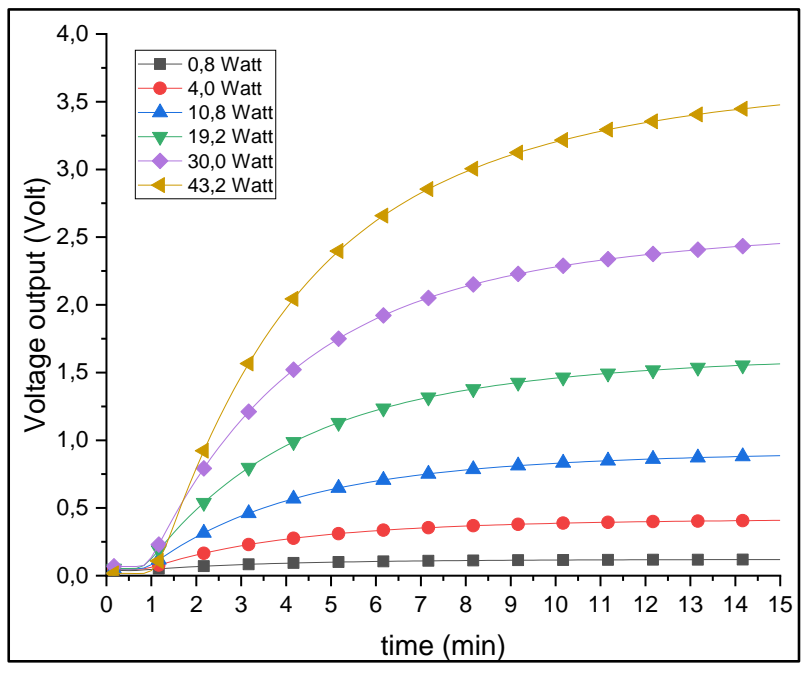

Fig. 8. Thermoelectric module voltage output at $144 \Omega$ load.

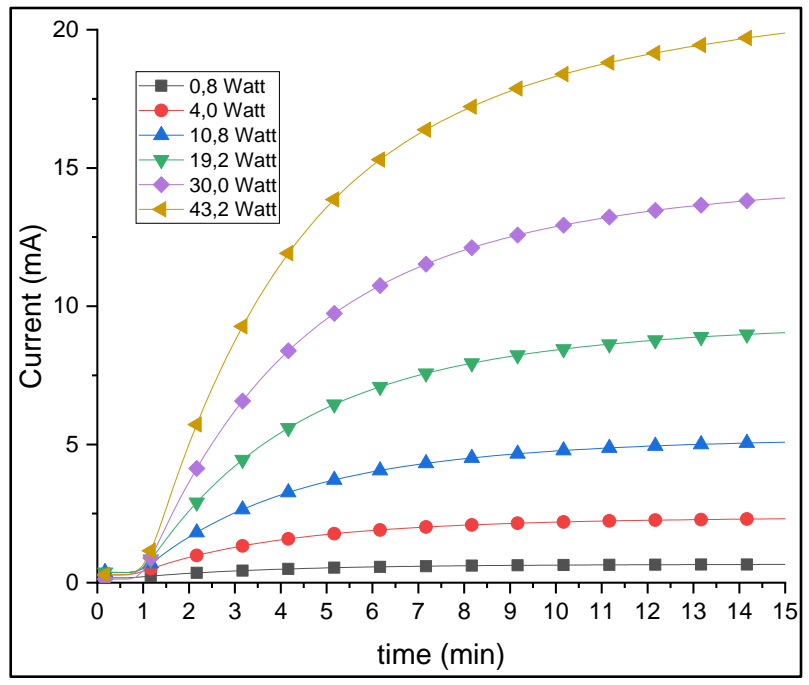

Fig. 9. Thermoelectric module current output at $144 \Omega$ load.

Each variation produces different voltage and current output at each load. In Table 2, we can see the voltage and current outputs at load $210 \Omega$. At 0.8 Watt variation of power, the maximum output voltage is 0.11 $\mathrm{V}$, and the maximum current is $0.49 \mathrm{~mA}$. Whereas the 43.2 Watt power variation produces a maximum output voltage of $3.77 \mathrm{~V}$ and a maximum current of $15.08 \mathrm{~mA}$. The higher the power input, the higher the output voltage and current generated of the thermoelectricNot much different from the load of $210 \Omega$, the load of 182 $\Omega$ and $144 \Omega$ also has the same characteristic and voltage output. However, the current value of load $182 \Omega$ and $144 \Omega$ is different from the load of $210 \Omega$. At the load of $182 \Omega$ presented at Table 3 , the value of the resulting current is a maximum of $19.23 \mathrm{~mA}$ in variations 43.2 Watt, and at 0.8 Watt variation, the current generated is $0.62 \mathrm{~mA}$. While at the $144 \Omega$ loads, the maximum current generated is $21.22 \mathrm{~mA}$ at 43.2 Watt variation, and the lowest is $0.66 \mathrm{~mA}$ at the $0.8 \mathrm{Watt}$ variation (Table 4 ).
Table 2. Thermoelectric module output value compared to power input at $210 \Omega$ load.

\begin{tabular}{ccc}
\hline $\begin{array}{c}\boldsymbol{P}_{\text {in }} \\
\text { (Watt) }\end{array}$ & $\begin{array}{c}\boldsymbol{V}_{\text {out }} \\
\text { (Volt) }\end{array}$ & $\begin{array}{c}\boldsymbol{I}_{\text {out }} \\
(\mathbf{m A})\end{array}$ \\
\hline 0.8 & 0.11 & 0.49 \\
4.0 & 0.42 & 1.74 \\
10.8 & 0.92 & 3.77 \\
19.2 & 1.65 & 6.62 \\
30.0 & 2.64 & 10.64 \\
43.2 & 3.77 & 15.08 \\
\hline
\end{tabular}

Table 3. Thermoelectric module output value compared to power input at $182 \Omega$ load.

\begin{tabular}{ccc}
\hline $\begin{array}{c}\boldsymbol{P}_{\text {in }} \\
\text { (Watt) }\end{array}$ & $\begin{array}{c}\boldsymbol{V}_{\text {out }} \\
\text { (Volt) }\end{array}$ & $\begin{array}{c}\boldsymbol{I}_{\text {out }} \\
(\mathbf{m A})\end{array}$ \\
\hline 0.8 & 0.11 & 0.62 \\
4.0 & 0.42 & 2.18 \\
10.8 & 0.92 & 4.80 \\
19.2 & 1.64 & 8.53 \\
30.0 & 2.57 & 13.39 \\
43.2 & 3.69 & 19.23 \\
\hline
\end{tabular}

Table 4. Thermoelectric module output value compared to power input at $144 \Omega$ load.

\begin{tabular}{ccc}
\hline $\begin{array}{c}\boldsymbol{P}_{\text {in }} \\
\text { (Watt) }\end{array}$ & $\begin{array}{c}\boldsymbol{V}_{\text {out }} \\
\text { (Volt) }\end{array}$ & $\begin{array}{c}\boldsymbol{I}_{\text {out }} \\
(\mathbf{m A})\end{array}$ \\
\hline 0.8 & 0.11 & 0.66 \\
4.0 & 0.40 & 2.34 \\
10.8 & 0.92 & 5.27 \\
19.2 & 1.64 & 9.46 \\
30.0 & 2.57 & 14.80 \\
43.2 & 3.69 & 21.22 \\
\hline
\end{tabular}

The difference in output voltage and current flowing in the circuit is influenced by temperature difference that occurs at the sides of the thermoelectric module [20]. Fig. 10 presented a graph of the increase in temperature when the heater voltage variation is carried out in stages. When the heater temperature increases, the temperature on the cold side of the thermoelectric module will also increase. This is because the process of heat transfer occurs from the hot side of the thermoelectric module to the cold side of the thermoelectric module [22]. The cold side of the thermoelectric module is cooled by the evaporator section of the heat pipe. The evaporator temperature can be assumed to be the same as the cold side temperature of the thermoelectric module because of its attached position. The evaporator temperature rise is not proportional to the heater temperature rise. This causes an increase in temperature difference in each variation. The highest temperature difference is $67.57{ }^{\circ} \mathrm{C}$. The value obtained from the heater temperature is $102.09{ }^{\circ} \mathrm{C}$ and the evaporator temperature is $34.52{ }^{\circ} \mathrm{C}$. 


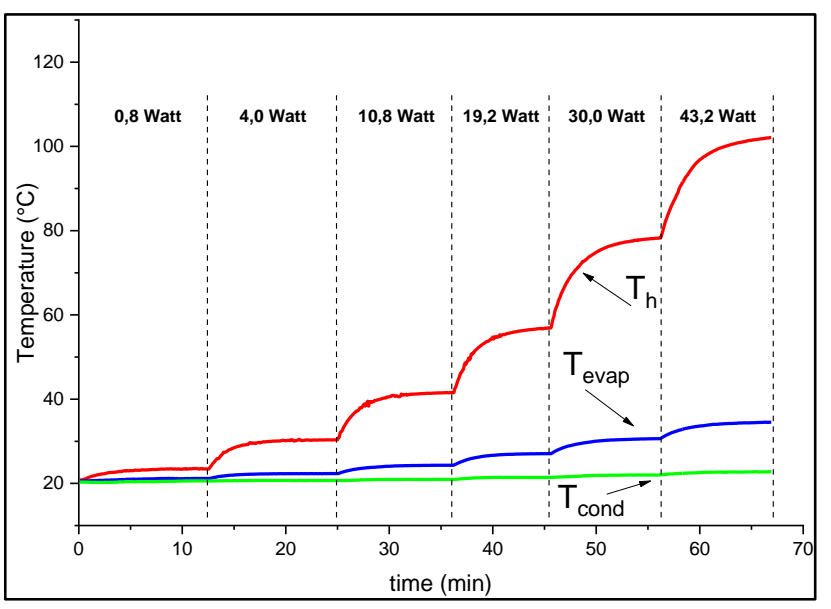

Fig. 10. Graph of temperature Th, Tevap, and Tcond.

Table 5. Thermoelectric module output value compared to power input.

\begin{tabular}{cccc}
\hline $\begin{array}{c}\boldsymbol{P}_{\text {in }} \\
\text { (Watt) }\end{array}$ & $\begin{array}{c}\boldsymbol{T}_{\boldsymbol{h}} \\
\left.\mathbf{(}^{\circ} \mathbf{C}\right)\end{array}$ & $\begin{array}{c}\boldsymbol{T}_{\text {evap }} \\
\left({ }^{\circ} \mathbf{C}\right)\end{array}$ & $\begin{array}{l}\boldsymbol{T}_{\text {cond }} \\
\left({ }^{\circ} \mathbf{C}\right)\end{array}$ \\
\hline 0.8 & 23.56 & 21.19 & 20.60 \\
4.0 & 30.28 & 22.32 & 20.68 \\
10.8 & 41.47 & 24.23 & 20.94 \\
19.2 & 56.78 & 27.05 & 21.94 \\
30.0 & 77.90 & 30.53 & 21.97 \\
43.2 & 102.09 & 34.52 & 22.70 \\
\hline
\end{tabular}

The temperature that occurs in a heat pipe is called the operating temperature [23]. The increase in temperature depends on changes in experimental variations. Variation changes are made when the temperature value of each point has reached stability.

In Fig. 10, the higher the evaporator temperature, the temperature of the condenser will increase as well. That is because there is heat transfer from the evaporator to the condenser. The working fluid in the evaporator section evaporates into the gas phase under vacuum condition and flows into a smaller pressure chamber that is in the condenser section [24]. Instead, the cooled working fluid in the condenser will then return to the evaporator section through the capillary wick. In addition, heat transfer also occurs in the copper walls of the heat pipe. It can be seen in Table 5 , the highest operating temperature value at heater power 43.2 Watts is $34.52{ }^{\circ} \mathrm{C}$ on the evaporator and $22.70{ }^{\circ} \mathrm{C}$ on the condenser. Whereas on the heater power $0.8 \mathrm{Watt}$, there was only a small temperature difference of $21.19{ }^{\circ} \mathrm{C}$ in the evaporator and $20.60{ }^{\circ} \mathrm{C}$ in the condenser. Thus, the heat pipe operating temperature is influenced by the amount of power input applied to the heat pipe. Besides, the position of the heat pipe also affects. In this experiment, the position of the heat pipe is against gravity, and the evaporator is on the top while the condenser is below. The orientation of the heat pipe against gravity has a lower effective thermal conductivity compared to the heat pipe assisted by gravity.

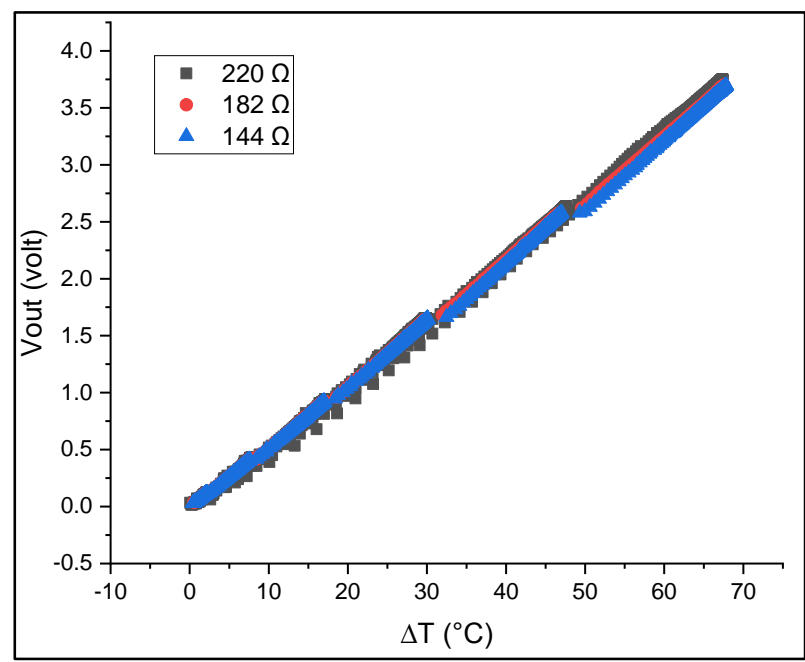

Fig. 11. Thermoelectric module voltage output to temperature difference.

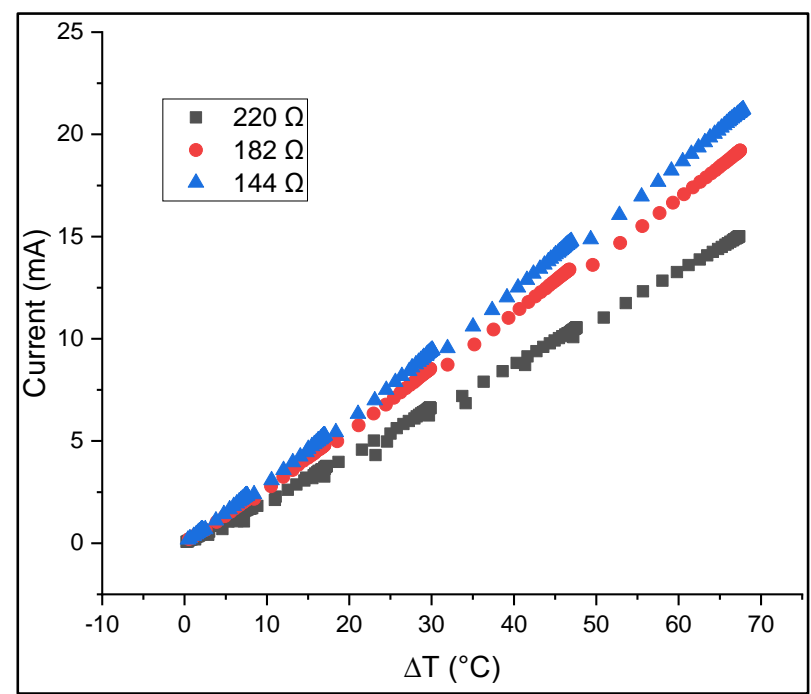

Fig. 12. Thermoelectric module current output to temperature difference.

From the temperature difference that occurs then the value of the voltage output and current output is plotted into the graph. The results can be seen in Fig. 11 and Fig. 12. Figure 11 is a graph of the voltage output compared to the temperature difference. There is no significant difference in the output voltage at each load. At the lowest temperature difference in $2.37{ }^{\circ} \mathrm{C}$, the result of output voltage is only $0.11 \mathrm{~V}$. Whereas the biggest temperature difference of $67.57^{\circ} \mathrm{C}$ produces the largest output voltage from $3.69 \mathrm{~V}$ to $3.77 \mathrm{~V}$.

Different from the output voltage graph, the current output produces a different graph. The smaller the load used, the higher the current will be presented while a large load produces a low current. The most significant current output is generated at a load of $144 \Omega$, while a small current is generated at a load of $210 \Omega$. A comparison graph between the current output generated and the temperature difference can be seen in Fig. 12. 


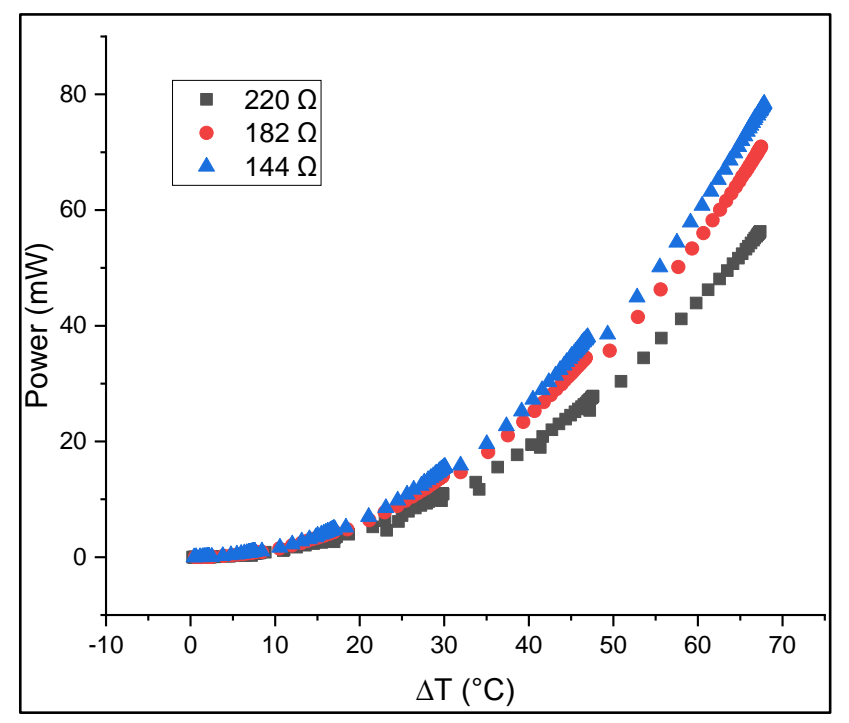

Fig. 13. Thermoelectric module power output compared to temperature difference.

Table 6. Thermoelectric module power output value in each load compared to temperature difference.

\begin{tabular}{ccccc}
\hline $\begin{array}{c}\boldsymbol{P}_{\text {in }} \\
\text { (Watt) }\end{array}$ & $\begin{array}{c}\boldsymbol{\Delta} \boldsymbol{T}_{\max } \\
\left({ }^{\circ} \mathbf{C}\right)\end{array}$ & $\begin{array}{c}\boldsymbol{P}_{\text {out }} \\
\mathbf{2 1 0} \boldsymbol{\Omega} \\
(\mathbf{m W})\end{array}$ & $\begin{array}{c}\boldsymbol{P}_{\text {out }} \\
\mathbf{1 8 2} \boldsymbol{\Omega} \\
(\mathbf{m W})\end{array}$ & $\begin{array}{c}\boldsymbol{P}_{\text {out }} \\
\mathbf{1 4 4} \boldsymbol{\Omega} \\
(\mathbf{m W})\end{array}$ \\
\hline 0.8 & 2.37 & 0.05 & 0.07 & 0.07 \\
4.0 & 7.96 & 0.73 & 0.91 & 0.96 \\
10.8 & 17.24 & 3.49 & 4.43 & 4.85 \\
19.2 & 29.73 & 10.92 & 14.02 & 15.60 \\
30.0 & 47.37 & 28.08 & 34.50 & 38.16 \\
43.2 & 67.57 & 56.81 & 71.12 & 78.41 \\
\hline
\end{tabular}

The graph in Fig. 13 shows the influence of temperature differences on the output power of the thermoelectric module. The power produced by the thermoelectric module is also increased by increasing temperature difference [25]. To get the amount of power, Eq. (4) is used with the value of $R_{L}$ is the value of the external load. The amount of power produced in each variation can be seen in Table 6 . The greater the temperature difference on the thermoelectric module the greater the power produced. The lowest temperature difference is $2.37{ }^{\circ} \mathrm{C}$ while the highest temperature difference is $67.57^{\circ} \mathrm{C}$. At load $210 \Omega$, the highest power produced is $56.81 \mathrm{~mW}$, and the lowest is only $0.05 \mathrm{~mW}$. While at load $182 \Omega$, the highest power produced is $71.12 \mathrm{~mW}$, and the lowest is $0.07 \mathrm{~mW}$. At load $144 \Omega$, the highest power produce is $78.41 \mathrm{~mW}$, and the lowest is $0.07 \mathrm{~mW}$.

The difference in output power of the thermoelectric module is influenced by the voltage and current flowing in the circuit [20]. As seen in Fig. 13, each load has a different graph and forms a curve. This is because power is a quadratic function of current (Eq. (4)). The higher the current flowing, the greater the power generated by the thermoelectric module. The largest current will be occurring by the smallest load because the resistance through which the current will be lower.

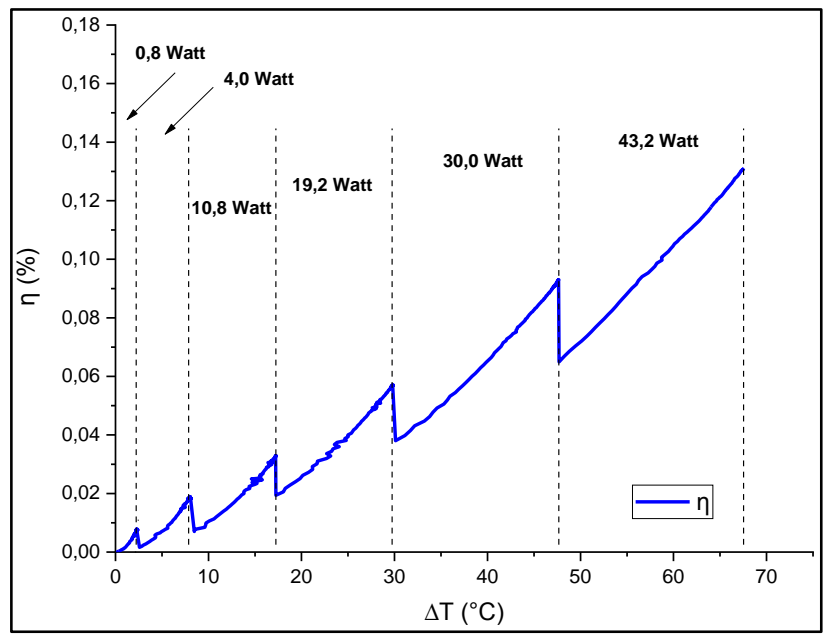

Fig. 14. Graph of efficiency by temperature difference.

Table 7. Thermoelectric module efficiency value compared to temperature difference.

\begin{tabular}{ccc}
\hline $\begin{array}{c}\boldsymbol{P}_{\text {in }} \\
\text { (Watt) }\end{array}$ & $\begin{array}{c}\boldsymbol{\Delta} \boldsymbol{T}_{\max } \\
\left({ }^{\circ} \mathbf{C}\right)\end{array}$ & $\begin{array}{c}\boldsymbol{\eta} \\
\mathbf{( \% )}\end{array}$ \\
\hline 0.8 & 2.37 & 0.007 \\
4.0 & 7.96 & 0.019 \\
10.8 & 17.24 & 0.033 \\
19.2 & 29.73 & 0.057 \\
30.0 & 47.37 & 0.093 \\
43.2 & 67.57 & 0.130 \\
\hline
\end{tabular}

Figure 14 shows a graph of the efficiency of the thermoelectric module on temperature differences. Efficiency value is obtained by using Eq. (5). In the graph (Fig. 14), it can be seen that there is an increase in efficiency at each increase in temperature difference. However, for each change in variation, the efficiency test will go down first before then rising again. This is due to the time needed by the heater to raise the temperature of the heater until it is stable when heater changes are made. The time needed by the heater to be stable then causes a decrease in efficiency because the increase in evaporator temperature is not proportional to the heater temperature. The highest efficiency is obtained at 43.2 Watt input power which is equal to $0.13 \%$. This value is obtained at a temperature difference of $67.57{ }^{\circ} \mathrm{C}$. While the average efficiency obtained is $0.04 \%$. While the lowest efficiency is in the variation 0.8 Watt which is equal to $0.007 \%$ with a temperature difference of $2.37^{\circ} \mathrm{C}$. The maximum efficiency obtained is quite small; this is because the thermoelectric module used is the thermoelectric module commonly used for heat recovery that is easily obtained by anyone. Theoretically, the efficiency of the thermoelectric module will increase with increasing temperature difference [26]. However, the efficiency of thermoelectric modules has a maximum limit due to heat transfer laws and the power output characteristic [27]. Besides, efficiency is also influenced by the temperature-dependent figure of the merit of the thermoelectric material [28]. 


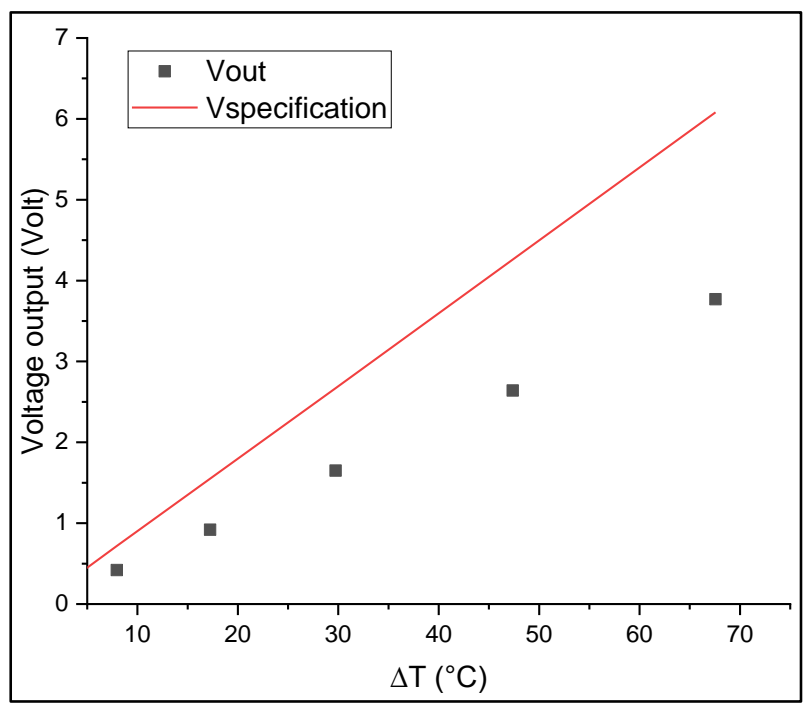

Fig. 15. Actual voltage output value compared to specification voltage output.

Table 8. Performance of the thermoelectric module.

\begin{tabular}{ccccc}
\hline $\begin{array}{c}\boldsymbol{P}_{\text {in }} \\
\text { (Watt) }\end{array}$ & $\begin{array}{c}\boldsymbol{\Delta} \boldsymbol{T}_{\text {max }} \\
\left({ }^{\circ} \mathbf{C}\right)\end{array}$ & $\begin{array}{c}\boldsymbol{V}_{\text {specification }} \\
(\text { Volt) }\end{array}$ & $\begin{array}{c}\boldsymbol{V}_{\text {out }} \\
(\text { Volt) }\end{array}$ & $\begin{array}{c}\text { Performance } \\
(\mathbf{\%})\end{array}$ \\
\hline 0.8 & 2.37 & 0.21 & 0.11 & 52.38 \\
4.0 & 7.96 & 0.72 & 0.42 & 58.33 \\
10.8 & 17.24 & 1.55 & 0.92 & 59.35 \\
19.2 & 29.73 & 2.67 & 1.65 & 61.80 \\
30.0 & 47.37 & 4.26 & 2.64 & 61.97 \\
43.2 & 67.57 & 6.08 & 3.77 & 62.00 \\
\hline
\end{tabular}

Another performance to note is the ability of the thermoelectric module to generate voltage. In Fig. 15 can be seen the module performance between the actual voltage generated with the specification pitch that should be generated. The $\mathrm{V}_{\text {specification }}$ line is the specification voltage that should be produced by the thermoelectric module, while the $\mathrm{V}_{\text {out }}$ points are the actual voltage generated by the thermoelectric module. $V_{\text {specification }}$ is obtained from the Seebeck coefficient of the thermoelectric module that is equal to $0.09 \mathrm{~V} / \mathrm{K}$. The average thermoelectric module performance is $59.30 \%$. The highest performance is $62.00 \%$ obtained from a temperature difference of $67.57{ }^{\circ} \mathrm{C}$ while the lowest performance is $52.38 \%$ obtained from a temperature difference of $2.37^{\circ} \mathrm{C}$. The performance can be caused by voltage losses on the cable, module quality, or heat losses in the experimental circuit.

\section{Conclusion}

Based on the results of data processing and analysis that has been done, this research can be concluded. The maximum voltage obtained from testing the experiment is $3.77 \mathrm{~V}$, which is obtained from the thermoelectric module temperature difference of $67.57^{\circ} \mathrm{C}$. The temperature difference is found in the experimental water temperature conditions of $20^{\circ} \mathrm{C}$ and the heater temperature of $102,09^{\circ} \mathrm{C}$. The highest heat pipe cooling ability in this study was to produce a temperature difference in the thermoelectric module of $67.57^{\circ} \mathrm{C}$. When the heater temperature reached $102.09^{\circ} \mathrm{C}$, the heat pipe was able to reduce thermoelectric module temperature until it reached $34.52{ }^{\circ} \mathrm{C}$. The highest efficiency is $0.13 \%$ it was obtained with a temperature difference of $67.57{ }^{\circ} \mathrm{C}$. The average efficiency of the thermoelectric module is $0.04 \%$ and the average thermoelectric module performance is $59.30 \%$

\section{Acknowledgment}

The author would like to thank the Directorate of Research and Community Engagements Universitas Indonesia (DRPM UI) for funding this research through the PITTA 2019 scheme with contract number NKB0738/UN2.R3.1/HKP.05.00/2019.

\section{References}

[1] S. J. K. R. Biro Perencanaan KKP RI, Laporan Tabunan Kementerian Kelautan dan Perikanan Tabun 2017. Jakarta: Kementrian Kelautan dan Perikanan RI, 2018.

[2] C. Boyd, Water Quality An Introduction, 2nd ed. New London: Springer, 2015.

[3] IPSOS Business Consulting, Indonesia's Aquaculture Industry. 2016.

[4] EU Indonesia Business Network, "EIBN Sector Report Fisheries and Aquaculture," 2017.

[5] P. Senff, S. Partelow, L. F. Indriana, N. Buhari, and A. Kunzmann, "Improving pond aquaculture production on Lombok, Indonesia," Aquaculture, vol. 497, no. November 2017, pp. 64-73, 2018.

[6] A. Pariawan, "Effect of Light Intensity on the Carotenoid Content of Chlorella sp.," 2014.

[7] L. J. Fleckenstein, T. W. Tierney, J. C. Fisk, and A. J. Ray, "Effects of supplemental LED lighting on water quality and Pacific white shrimp (Litopenaeus vannamei) performance in intensive recirculating systems," Aquaculture, vol. 504, pp. 219-226, 2019.

[8] Tim Perikanan WWF-Indonesia, Better Management Practices Budidaya Udang Vannamei Tambak Semi Intensif dengan Instalasi Pengolahan Air LImbah (IPAL), Seri Panduan Perikanan Skala Kecil. 2014.

[9] A. Kumar, K. Singh, S. Verma, and R. Das, "Inverse prediction and optimization analysis of a solar pond powering a thermoelectric generator," Sol. Energy, vol. 169, pp. 658-672, 2018.

[10] W. Lee and J. Lee, "Development of a compact thermoelectric generator consisting of printed circuit heat exchangers," Energy Convers. Manag., vol. 171, pp. 1302-1310, 2018.

[11] D. N. Kossyvakis, C. G. Vossou, C. G. Provatidis, and E. V. Hristoforou, "Computational analysis and performance optimization of a solar thermoelectric generator," Renew. Energy, vol. 81, pp. 150-161, 2015.

[12] D. M. Rowe, Thermoelectrics Handbook. Taylor \& Francis Group, 2006.

[13] A. E. Özdemir, Y. Köysal, E. Özbaş, and T. Atalay, 
"The experimental design of solar heating thermoelectric generator with wind cooling chimney," Energy Convers. Manag., vol. 98, pp. 127133, 2015.

[14] A. S. El-Adl, M. G. Mousa, and A. A. Hegazi, "Performance analysis of a passively cooled thermoelectric generator," Energy Convers. Manag., vol. 173, pp. 399-411, 2018.

[15] H. Hazama, Y. Masuoka, A. Suzumura, M. Matsubara, and S. Tajima, "Cylindrical thermoelectric generator with water heating system for high solar energy conversion e ffi ciency," Appl. Energy, vol. 226, pp. 381-388, 2018.

[16] A. Date, A. Date, C. Dixon, and A. Akbarzadeh, "Theoretical and experimental study on heat pipe cooled thermoelectric generators with water heating using concentrated solar thermal energy," Sol. Energy, vol. 105, pp. 656-668, 2014.

[17] G. Omer, A. H. Yavuz, and R. Ahiska, "Heat pipes thermoelectric solar collectors for energy applications," Int. J. Hydrogen Energy, vol. 42, no. 12, pp. 8310-8313, 2017.

[18] S. M. Khairnasov and A. M. Naumova, "Heat pipes application to solar energy systems," Appl. Sol. Energy, vol. 52, no. 1, pp. 47-60, 2016.

[19] N. Putra and B. Ariantara, "Electric motor thermal management system using L-shaped flat heat pipes," Appl. Therm. Eng., vol. 126, pp. 1156-1163, 2017.

[20] A. A. Negash, T. Y. Kim, and G. Cho, "Effect of electrical array configuration of thermoelectric modules on waste heat recovery of thermoelectric generator," Sensors Actuators, A Phys., vol. 260, pp. 212-219, 2017.

[21] I. I. Hakim, N. Putra, and M. Usman, "Analysis of the use of thermoelectric generator and heat pipe for waste heat utilization," E3S Web Conf., vol. 67, p. $02057,2018$.
[22] Y. Li, S. Wang, and Y. Zhao, "Experimental study on the influence of the core flow heat transfer enhancement on the performance of thermoelectric generator," Energy Procedia, vol. 105, pp. 901-907, 2017.

[23] X. Chen, Y. Lin, S. Shao, and W. Wu, "Study on heat transfer characteristics of ethane pulsating heat pipe in middle-low temperature region," Appl. Therm. Eng., vol. 152, pp. 697-705, 2019.

[24] A. Siricharoenpanich, S. Wiriyasart, A. Srichat, and P. Naphon, "Case Studies in Thermal Engineering Thermal management system of CPU cooling with a novel short heat pipe cooling system," Case Stud. Therm. Eng., vol. 15, p. 100545, 2019.

[25] S. Liu et al., "Micro-thermoelectric generators based on through glass pillars with high output voltage enabled by large temperature difference," Appl. Energy, vol. 225, pp. 600-610, 2018.

[26] P. Jood, M. Ohta, P. Jood, M. Ohta, A. Yamamoto, and M. G. Kanatzidis, "Excessively doped PbTe with Ge-induced nanostructures enables highefficiency thermoelectric modules excessively doped $\mathrm{PbTe}$ with Ge-induced nanostructures enables highefficiency thermoelectric modules," Joule, vol. 2, no. 7, pp. 1339-1355, 2018.

[27] L. Chen, F. Meng, and F. Sun, "Sharif University of Technology Maximum power and efficiency of an irreversible thermoelectric generator with a generalized heat transfer law," Sci. Iran., vol. 19, no. 5, pp. 1337-1345, 2012.

[28] M. L. Olsen, E. L. Warren, P. A. Parilla, E. S. Toberer, and C. E. Kennedy, "A high-temperature, high-efficiency solar thermoelectric generator prototype," Energy Procedia, vol. 49, pp. 1460-1469, 2014. 


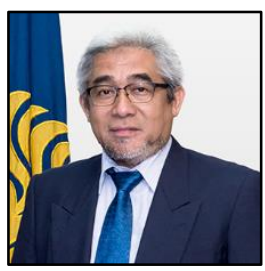

Imansyah Ibnu Hakim was born in Jakarta, Indonesia, in 1968. He received the Bachelor's degree in mechanical engineering from Faculty of Engineering, Universitas Indonesia, Depok, in 1993, Master degree in advance energy engineering science from Interdisciplinary Graduate School of Engineering Sciences, Kyushu University, Japan, in 2000, and the Doctor degree in mechanical engineering from Faculty of Engineering, Universitas Indonesia, Depok in 2012.

From 2000 to 2002, He was a teaching assistant in the Department of Advance Energy Engineering Science from Interdisciplinary Graduate School of Engineering Sciences, Kyushu University. He is an Associate Dean for Cooperation and Venture, Faculty of Engineering, Universitas Indonesia. Since 2004, He has been a lecturer in the Mechanical Engineering Department, Faculty of Engineering, Universitas Indonesia. He has more than 40 publications in the reputable journal and has published the paper in many journals majoring in thermophoresis, heat pipe, nanofluids, thermoelectric, phase-change material, and liquid smoke (pyrolysis).

Dr. Ir. Imansyah was a member of The Institution of Engineer Indonesia as Insinyur Profesional Madya (IPM) and also holds two patents about thermal precipitator for collecting smoke particulates and thermoelectric-based multifunctional heaters or coolers.

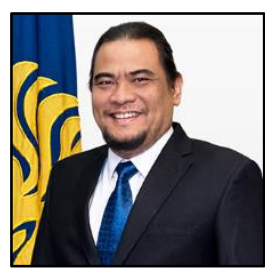

Nandy Setiadi Djaya Putra was born in Palembang, Indonesia, in 1970. He received a Bachelor's degree in mechanical engineering from Universitas Indonesia in 1994, Master and Ph.D. in heat transfer in dispersed material mechanical engineering from The University of Federal Armed Forces, Hamburg, Germany, in 2002 and received the professor in 2009.

From 1998 to 2002, He was a research member of The University of Federal Armed Forces, Hamburg, during Ph.D. study and published more than five papers in the reputable journal. Since 2002, He has been a lecturer in the Mechanical Engineering Department, Faculty of Engineering, Universitas Indonesia, and from 2009 as a professor. He is a Vice Dean for Resources, Venture, and General Administration in Faculty of Engineering, Universitas Indonesia. He is a leader in Applied heat transfer research group and evaporative cooling. He was leading the research with Heat Pipe Nanofluids Thermoelectric PCM and Liquid Smoke (pyrolysis). He has more than 100 publications in the reputable journal and has published the paper in many journals majoring in heat pipe, nanofluids, thermoelectric, phase-change material and liquid smoke (pyrolysis). $\mathrm{He}$ is the author of six books, which has been published as the teaching book. He also has three inventions and one patent. He has been involved as a reviewer in some journals.

Prof. Dr.-Ing Nandy was a recipient of 5th The Best Researcher in Universitas Indonesia in 2011, Best Paper Award 6th International Meeting on Advanced Thermofluid 2013, the most prospective innovation researcher award from the ministry of research and technology (2015) and more than five award from Universitas Indonesia and government.

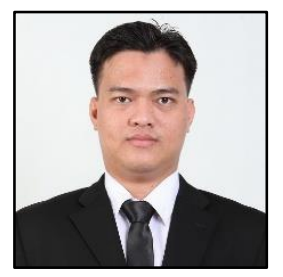

Yovan Okta Ananda was born in Bogor, Jawa Barat, Indonesia, in 1994. He received the Diploma degrees in mechanical engineering from the State Polytechnic of Jakarta, Depok, in 2015 and the Bachelor's degree in mechanical engineering from Faculty of Engineering, Universitas Indonesia, Depok, in 2019.

From 2012 to 2015, He was a technician apprentice in Holcim Indonesia Ltd. with specialization in condition-based maintenance and monitoring. Since $2018 \mathrm{He}$ was a research member of Applied Heat Transfer Research Group (AHTRG) in Mechanical Engineering Department, Universitas Indonesia. His research interests include thermoelectric generator and heat pipe.

Mr. Yovan was a recipient of the Best Paper Award for the Energy Storage Symposium in The 4th International Tropical Renewable Energy Conference 2019. 